\title{
Measuring the shadow economy using company managers
}

\author{
Tālis J. Putnin̦šs ${ }^{a, b, *}$ and Arnis Sauka ${ }^{b, *}$ \\ ${ }^{a}$ University of Technology, Sydney, Australia \\ ${ }^{\mathrm{b}}$ Stockholm School of Economics in Riga, Latvia
}

$\underline{\text { Journal of Comparative Economics (forthcoming) }}$

\begin{abstract}
This study develops a method that uses surveys of company managers to measure the size of a shadow economy. Our method is based on the premise that company managers are the most likely to know how much business income and wages go unreported due to their unique position in dealing with both of these types of income. We use a range of survey design features to maximize the truthfulness of responses. Our method combines estimates of misreported business income, unregistered or hidden employees, and unreported wages, to arrive at an estimate of the size of a shadow economy as a percentage of GDP. This approach differs from most other studies of shadow economies, which largely focus on using macro indicators. We illustrate the application of our method to three new EU member countries. We also analyze the factors that influence companies' participation in the shadow economy.
\end{abstract}

Keywords: shadow economy; tax evasion; company managers; new EU members; GDP

JEL classifications: E26; O17; E01; P24; H26; H32

${ }^{*}$ E-mail address: talis.putnins@ @sseriga.edu (T.J. Putninšs); arnis.sauka@ sseriga.edu (A. Sauka). 


\section{Introduction}

The size of a shadow economy is an important issue because informal production has a number of negative consequences. First, informal production and tax evasion can create a vicious spiral: individuals go underground to escape taxes and social welfare contributions, eroding the tax and social security bases, causing increases in tax rates and/or budget deficits, pushing more production underground and ultimately weakening the economic and social basis for collective arrangements. Second, tax evasion can hamper economic growth by diverting resources from productive uses (producing useful goods and services) to unproductive ones (mechanisms and schemes to conceal income, monitoring of tax compliance, issuance and collection of penalties for non-compliance). Third, informal production can constrain companies' ability to obtain debt or equity financing for productive investment because potential creditors/investors cannot verify the true (concealed) cash flows of the company. This can further impede growth. Finally, shadow activities distort official statistics such as GDP, which are important signals to policy makers.

Like most phenomena that are not directly observable, shadow economies are difficult to measure. Despite decades of research, the literature is yet to arrive at a consensus on what are the best or most reliable methods of measuring a shadow economy. Importantly, the lack of a broadly accepted method of measurement has hampered research efforts aimed at understanding shadow economies: their size, their determinants, their relation to the stages of economic development, and their responsiveness to various policy measures. For example, Feige and Urban (2008) examine the main 'macro' approaches to measuring the shadow economy and find alarmingly varied estimates across the methods and a lack of convergence. This leads them to conclude "it is time to acknowledge how little we really know about unobserved economies despite forty years of effort to measure their size and growth" (p. 300) and suggest "econometricians must be encouraged not only to critique existing macro methods but to develop constructive alternative means of measurement" (p. 300). This paper aims to do exactly that.

This study makes a methodological contribution by developing an index that measures the size of a shadow economy as a percentage of GDP. We do not seek to directly resolve the debate about advantages, disadvantage, accuracy and reliability of existing methods; instead, we aim to extend the promising group of 'direct methods' by developing and testing a method that has several novel features. Our hope is that with continued refinement of existing methods their estimates will begin to converge. 
We use the term 'shadow economy' (also 'informal' or 'unreported' economy) to refer to all legal production of goods and services that is deliberately concealed from public authorities. ${ }^{1}$ In contrast to studies that focus on analyzing aggregate macroeconomic data, our estimates of the size of a shadow economy are derived from surveys of company managers. The reasoning for this approach is that those most likely to know how much business income and wages go unreported are the company managers that themselves engage in the misreporting and shadow production. In essence, GDP measured using the income approach is made up of personal income (wages) and corporate income (business profits). Therefore, the shadow economy can be measured as the sum of deliberately concealed wages (including wages paid to unregistered workers) and unreported business profits. Our motivation for turning to company managers to measure the shadow economy is they are in the unique position of simultaneously knowing about both of these components of the shadow economy - unreported wages and unreported business profits. The challenge is eliciting maximally truthful and precise responses. To do this, our method makes use of a number of surveying and data collection techniques shown in previous studies to be effective in eliciting more truthful responses.

The shadow economy index combines estimates of misreported business income, unregistered or hidden employees, as well as unreported "envelope" wages. Our method requires fewer assumptions than most existing methods of measuring the shadow economy, in particular compared to methods based on macro indicators. Our shadow economy index can be used through time or across sectors and economies and thus is a useful tool for evaluating the effectiveness of policy designed to decrease the size of a shadow economy. Our approach has two main advantages compared to methods using aggregated macroeconomic data: (i) it produces micro-level (firm-level) estimates, which can be used to examine the structure of the shadow economy and thus guide policies that target problematic sectors or types of firms, or test theories about factors that influence involvement in the shadow economy; and (ii) it is precise about what parts of observed or unobserved production are included in the estimates. Therefore estimates from our approach may be used in adjusting GDP to account for shadow production.

\footnotetext{
${ }^{1}$ This definition corresponds to what the Organization for Economic Co-operation and Development (OECD) in their comprehensive 2002 handbook "Measuring the Non-observed Economy" as well as the System of National Accounts (SNA 1993) refer to as "underground production". It is also consistent with definitions employed by other researchers (e.g., the World Bank study of 162 countries by Schneider, Buehn and Montenegro (2010)).
} 
A limitation of our approach is that despite the various surveying and data collection techniques that we use to maximize the truthfulness of responses, some respondents may still provide untruthful responses due to the sensitive nature of this topic or due to fear of being exposed to their government authorities. As a result, our estimates may understate the true size of the shadow economy and can be treated conservatively as lower-bound estimates. Furthermore, our method is more expensive to apply than indirect macro methods.

Our paper is not the first to use surveys to estimate the size of the shadow economy, ${ }^{2}$ but it extends this literature in three main ways. First, to our knowledge, our method is the first to focus specifically on company managers as the source of information about the shadow economy, motivated by the observation that they play a central role in determining both main components of the shadow economy (misreported business income and misreported wages). This allows us to concurrently obtain estimates of both components, which when combined produce an estimate of the full shadow economy. This contrasts with the typical survey-based approach of focusing on households or individuals. Second, our method produces an estimate of the shadow economy that is both well-defined and expressed as a proportion of true GDP. This is achieved through careful framing of the survey questions to elicit the quantities of interest, and a set of equations that exploit accounting identities within the system of national accounts to map survey responses into a proportional measure of the shadow economy. This feature of our method is what gives it potential to be used in adjusting official GDP estimates to account for the shadow economy. Third, our method is transparent, tested, adequately documented (including a questionnaire form), and sufficiently general such that it can be applied in a large number of countries. Our method only requires the following two sources of non-survey data: (i) a list of local companies with contact details (available from databases such as Bureau Van Dijk's Orbis, or national business registries); and (ii) national accounts estimates of employees' remuneration and gross operating income of firms (available from national statistics bureaus or agencies such as Eurostat).

To illustrate the application of our method and the type of information that it is capable of producing, we use it to measure the size of the shadow economy in three new EU member states: Estonia, Latvia and Lithuania. Our choice of these three countries is

\footnotetext{
${ }^{2}$ For example, see Isachsen and Strom, 1985; Morgensen et al., 1995; Kazemier and van Eck, 1992; Kim, 2003; Hanousek and Palda, 2004; Gerxhani, 2007.
} 
motivated by several considerations. First, anecdotal evidence suggests former Soviet Union countries such as the Baltic countries have relatively large shadow economies and thus offer a rich setting to study the determinants and effects of shadow activity. Second, the Baltic countries are often outliers in cross-country shadow economy studies and estimates of their shadow economies are highly varied across different estimation methods. Existing methods fail to agree on the size of the Baltic shadow economies, suggesting the need for further evidence. Third, the economies of the Baltic countries, both official and unofficial, are rapidly changing and thus allow for interesting analysis of the dynamics of shadow economies. Fourth, since 2010, the governments of the Baltic countries have implemented many policy measures designed to combat the shadow economies, allowing analysis of the effectiveness of these policy measures. We survey approximately 500 company owners/managers in each of the three countries in 2011, 2012 and 2013, creating a short dynamic panel of shadow economy estimates between 2009-2012.

In addition to documenting the size and dynamics of the shadow economies for the three countries, we illustrate the comparatively rich information produced using our method by testing the factors that influence participation in the shadow economy. We find that firms that are dissatisfied with the tax system or with the government tend to engage in more shadow activity. This result is consistent with previous research on tax evasion, and has implications for policies to reduce the size of the shadow economy. We also find that smaller, younger firms engage in proportionally more shadow activity than larger, older firms, consistent with the anecdotal evidence that tax evasion is used by firms to gain a competitive edge, and that having an edge is important in competing in an established market. Finally, the level of tax evasion and deliberate misreporting is responsive to the perceived probabilities of being caught and to the expected penalties for being caught. This last finding is consistent with rational expectations models of tax evasion, but until now has received only limited empirical support.

The findings of this study also have a number of policy implications. First, tax compliance can be encouraged by addressing the high level of dissatisfaction with the tax system and with government, e.g., making tax policy more stable and increasing the transparency with which taxes are spent. The level of shadow activity can also be reduced by increasing the probability of detection, e.g., increasing the number of tax audits, introducing whistle-blower schemes that provide incentives to report information to authorities about non-compliant companies, and investment in tax evasion detection 
technology. Second, the relatively large size of shadow economies in the Baltic countries and their different expansion/contraction trends are likely to cause significant error in official estimates of GDP and its rates of change.

In the next section we review existing methods of measuring the size of the shadow economy. We then describe our method. Section 4 presents results on the size and determinants of the shadow economies in the Baltic countries, and Section 5 contains conclusions.

\section{Approaches to measuring the shadow economy}

Existing methods for measuring the shadow economy can be divided into indirect and direct approaches. Indirect approaches, also sometimes known as 'macro' methods, are all built on the notion that economic activity, whether reported or hidden, leaves behind observable traces or indicators, such as electricity usage, currency usage, transactions, official labor force participation rates, and so on. In essence, these methods use the observable indicators in various econometric specifications (in some cases also incorporating the causes of shadow activity) to estimate the true level of economic activity. Subtracting recorded economic activity from the estimate of true economic activity gives an estimate of the shadow economy.

Many of the indirect macro methods rely on a single indicator of economic activity. For example, the transactions approach is based on the assumption that the ratio of transactions to GDP is constant. ${ }^{3}$ The volume of transactions is estimated as the product of the money supply (cash and current deposits) and the velocity of circulation. By identifying a base year in which the level of shadow economy is likely to be very low (ideally zero), the method tracks the growth in total economic activity through time by observing growth in the volume of transactions. Subtracting the official GDP gives a measure of the shadow economy. A limitation of the method is that transactions are an imperfect measure of economic activity. For example, some transactions are unrelated to income generation, some money is used as a store of value, cash and deposits are sensitive to interest and inflation rates, and credit cards and other payment methods are also used for transactions. Similarly, several scholars have questioned the assumption of a constant ratio of transactions to GDP. Critics point out that the way transactions occur, and

\footnotetext{
${ }^{3}$ For more detailed descriptions of the transactions approach see Feige (1979) and Feige (1996).
} 
consequently the volume of transactions per unit GDP, changes through time and varies across countries causing errors in the shadow economy estimates.

The currency demand approach is based on the assumption that shadow transactions are undertaken with cash in order to avoid leaving evidence that authorities could find. ${ }^{4}$ Under this assumption, an increase in the size of the shadow economy increases the demand for cash. The method controls for factors that naturally affect the demand for cash, for example, payment habits, interest rates, prevalence of payment cards, and so on. This is done by regressing the cash to deposits ratio on the natural demand factors together with a set of factors that cause the shadow economy. The 'excess' cash demand (the demand that is not explained by the natural demand factors) is attributed to transactions in the shadow economy. The method is relatively easy to implement and therefore has been applied to a large number of countries. Criticisms of the method include the fact that not all transactions in the shadow economy are conducted with cash, many of the factors that contribute the shadow economy such as tax morale are often not included due to lack of data, and identifying a base case involving zero shadow activity is difficult and subjective.

The electric consumption method is based on the empirical observation that aggregate electricity usage is closely related to the level of economic activity. The method uses aggregate electricity consumption to obtain an estimate of total (official and unofficial) GDP. As with the previous methods, subtracting official GDP from the estimate of total GDP gives an estimate of the shadow economy. ${ }^{5}$ Criticisms of the method include the fact that not all shadow economy activities need a considerable amount of electricity, the need to calibrate against a zero shadow economy base case, the tendency for technological improvements or changes in the structure of the economy to affect the amount of electricity used in production, and differences across countries in the elasticity of electricity/GDP.

The macro methods described so far rely on a single indicator of economic activity. In contrast, the 'multiple indicator multiple cause' (MIMIC) method simultaneously considers multiple causes of the existence and growth of the shadow economy (e.g., tax burden, regulatory burden, attitudes towards paying taxes,

\footnotetext{
${ }^{4}$ For details and examples of currency demand methods see Cagan (1958), Gutmann (1977), Tanzi (1980), Tanzi (1983), Feige (1989), Johnson et al. (1998), Williams and Windebank (1995), Ahumada et al. (2007), and Feige and Urban (2008).

${ }^{5}$ For details and examples see Kaufmann and Kaliberda (1996), Johnson et al. (1997), Lackó (2000), Rosser et al. (2000), and Feige and Urban (2008).
} 
unemployment, etc.) and multiple effects or indicators of the shadow economy (e.g., labor force participation rates, weekly hours worked, etc.). ${ }^{6}$ MIMIC treats the size of the shadow economy as a latent (unobserved) variable and specifies structural equations relating the shadow economy to its causes and indicators. Given data on the assumed causes and indicators, the model's parameters can be estimated by maximum likelihood. From the parameters one can estimate the relative size of a shadow economy in one country or time period compared to another. To arrive at an estimate of the actual size of a shadow economy the relative estimates must be calibrated using an absolute measure of the shadow economy known or assumed to be correct. Often, MIMIC estimates are calibrated using estimates from the currency demand approach (e.g., Dell'Anno, 2007; Feld and Schneider, 2010; Schneider et al., 2010) making the absolute values sensitive not only to the MIMIC assumptions (and errors) but also the assumptions (and errors) of the currency demand approach.

The advantages of the MIMIC approach include its flexibility in that a researcher can include any list of causes and indicators deemed relevant; although this flexibility can also be viewed as a disadvantage because different causes/indicators lead to different estimates and the choice of which causes/indicators to use is somewhat subjective. Another advantage is that MIMIC, like other macro methods, is easier and cheaper to apply to a large sample of countries and/or time periods than direct methods. The MIMIC approach also has a number of disadvantages and has received strong criticism (e.g., Breusch, 2005a, 2005b). Its estimates are sensitive to the calibration method and at this stage there is no consensus on the most suitable calibration method. MIMIC estimates can also be unstable with respect to changes in the sample or model specification (e.g., Helberger and Knepel, 1988). Finally, like other macro methods, it is difficult to know what components of shadow activity are captured by the method (Buehn and Schneider, 2013).

An indirect method used by many statistical bureaus to incorporate some of the shadow economy into official GDP is based on discrepancies between income and expenditure statistics or between measures of labor supplied by households and labor used by companies. ${ }^{7}$ Because the income measure of GDP should be equal to the expenditure measure of GDP, the difference between the two (before making adjustments for shadow

\footnotetext{
${ }^{6}$ For further details and examples see Frey and Weck-Hannemann (1984), Giles (1999), Bajada and Schneider (2005), Dell'Anno (2007), and Schneider et al. (2010).

${ }^{7}$ For details and examples see MacAfee (1980), Petersen (1982), Thomas (1992), OECD (2002).
} 
activity) gives some indication of activity in the shadow economy. Similarly, the difference between the amount of labor households supply (e.g., from household surveys) and the amount that companies use (e.g., from social security records) gives some indication of unreported employment. A limitation of such approaches is that discrepancies reflect all omissions and errors throughout official statistics not just shadow activity. Furthermore, unless one of the measurements used in calculating the discrepancy captures all economic activity (all reported plus all unreported) and the other captures only reported activity, the discrepancy is likely to underestimate the size of the shadow economy.

In summary, the strength of indirect macro methods is that they can be calculated with relatively little cost and time, and thus relatively easily applied to compare the sizes of shadow economies across many countries or periods of time. Their main limitations include: (i) it is not clear which parts of observed or unobserved production these methods include; (ii) these methods draw on very simplified and often unrealistic assumptions; and (iii) the methods are not very stable since changes in assumptions can cause significantly different results.

The other group, direct methods, draws on direct micro-level observations, such as income audits or surveys. These are the most expensive and time consuming methods, but they manage to overcome many of the limitations that are typical in indirect methods. Direct methods are recommended for situations in which it is important to define exactly what part of production is being estimated, and when stability of the measurement is important. They also have the advantage of providing detailed information on the structure of the shadow economy across different sectors, regions, enterprises and individuals.

Tax audits conducted by the State Revenue Service (Internal Revenue Service in the US) have been used to estimate the level of tax evasion, or the 'tax gap'. ${ }^{8}$ The tax gap is related to the shadow economy because most activity in the shadow economy involves tax evasion. Tax audits are not perfect in identifying true income, including reported and unreported components. To overcome this limitation Feinstein $(1990,1991)$ develops 'detection controlled estimation' (DCE) methods that estimate the extent of tax evasion accounting for the fact that audits only detect a non-random fraction of all tax evasion. Audits are also typically non-random, which can bias estimates unless the estimation

\footnotetext{
${ }^{8}$ For example, see Clotefelter (1983), IRS (1983), Feige (1986) and Feinstein (1991).
} 
methods account for the lack of randomness. Another disadvantage of audits is that they are unlikely to capture unregistered workers.

The second group of direct methods is based on surveys. The key assumption in these methods is that the units of observation from which responses are collected, for instance, company managers, (i) know and, (ii) are willing to share information on the extent of their involvement in the shadow economy. Kazemier and van Eck (1992) provide an example of a micro-level survey that is used to estimate part of the shadow economy. They survey households about home maintenance and repair, including questions on the use of unreported labor and evasion of tax on construction materials. Zienkowski (1996) uses survey methods to estimate the amount of unreported labor within an economy. Kim (2003) uses Soviet family budget survey data containing various household income and expenditure items to estimate the dynamics of the informal economy of Soviet households between 1969 and 1990.

Survey-based approaches face the risk of underestimating the total size of the shadow economy due to non-response and untruthful response given the sensitive nature of the topic. This risk can be minimized by employing a number of survey and data collection techniques shown in previous studies to be effective in eliciting more truthful responses (e.g., Gerxhani, 2007; Kazemier and van Eck, 1992; Hanousek and Palda, 2004). These include guarantees of confidentiality, framing the survey as a study of satisfaction with government policy, gradually introducing the most sensitive questions after less sensitive questions, phrasing misreporting questions indirectly and, in the analysis, controlling for factors that correlate with potential untruthful response such as tolerance towards misreporting. Although these techniques help in obtaining more truthful responses, some respondents may still provide untruthful responses. For this reason, survey-based estimates of the size of a shadow economy are typically regarded as lowerbound estimates (e.g., Feld and Schneider, 2010; Williams, 2013). Survey-based methods are also relatively more expensive to apply than indirect macro methods. An advantage of survey-based methods is that they produce micro-level estimates, which characterize the structure of the shadow economy and can provide more detailed guidance to policymakers. Furthermore, it is precise about what parts of observed or unobserved production are included in the estimates and therefore may be used in adjusting GDP to account for shadow production. Finally, surveys are able to produce evidence on attitudes and perceptions, which can also be useful in guiding policy. 
For more detailed reviews of the different approaches to measuring the shadow economy and discussions of their advantages and disadvantages, see Schneider and Enste (2000), OECD (2002), Slemrod and Webber (2012), and Buehn and Schneider (2013).

\section{Method}

\subsection{Survey design}

Our method of measuring the size of the shadow economy draws on surveys of company owners/managers. The questionnaire form (see Appendix A) contains four main sections: (i) external influences; (ii) shadow activity; (iii) company and owner characteristics; and (iv) company managers' attitudes. To increase the response rate and truthfulness of responses the questionnaire begins with non-sensitive questions about satisfaction with the government and tax policy, before moving to more sensitive questions about shadow activity and deliberate misreporting. This 'gradual' approach is recommended by methodological studies of survey design in the context of tax evasion and the shadow economy (e.g., Gerxhani, 2007; and Kazemier and van Eck, 1992). Further, the survey is framed as a study of satisfaction with government policy, rather than a study of tax evasion and misreporting (similar to Hanousek and Palda, 2004).

In the first survey block, "external influences", respondents are asked to express their satisfaction with the State Revenue Service, tax policy, business legislation and government support for entrepreneurs in the respective country. The questions use a five point Likert scale, from "1" ("very unsatisfied") to "5" ("very satisfied"). The first section of the questionnaire also includes two questions related to social norms: tolerance towards tax evasion and towards bribery. Previous studies argue that people are likely to engage in more tax evasion when such behavior is tolerated (Baumol, 1990). The measures of tolerance serve a second important role as control variables for possible understating of the extent of shadow activity due to the sensitivity of the topic.

The second section of the questionnaire, "amount of informal business", is constructed based on the concepts of productive, unproductive and destructive entrepreneurship by Baumol (1990), assessment of 'deviance' or 'departure from norms' within organizations (e.g., Warren, 2003) and empirical studies of tax evasion in various settings (e.g., Fairlie, 2002; Aidis and Van Praag, 2007). We assess the amount of shadow activity by asking company managers to estimate the degree of underreporting of business income (net profits), underreporting of the number of employees, underreporting of salaries paid to employees and the percentage of revenues that firms pay in bribes. The 
second section of the questionnaire also elicits company managers' perceptions of the probability of being caught for various forms of shadow activity and the severity of penalties if caught deliberately misreporting.

We employ the 'indirect' approach for questions about informal business, asking company managers about 'firms in their industry' rather than 'their firm'. ${ }^{9}$ This approach is discussed by Gerxhani (2007) as a method of obtaining more truthful answers, and is used by Hanousek and Palda (2004), for example. The study conducted by Sauka (2008) shows, that even if asked indirectly, company owners/managers' answers can be attributed to the particular respondent or company that the respondent represents. ${ }^{10}$ Furthermore, experience from Sauka (2008) suggests that phone interviews are an appropriate tool to elicit information about tax evasion. ${ }^{11}$ Before conducting each interview, the interviewer ensures that they are talking to the company's owner (if that person is also the main manager, as is often the case with small companies) or the highest manager (in cases of delegated management).

We use the overlapping years (e.g., answers in both the 2013 survey and 2012 survey about the level of shadow activity in 2011) to filter out inconsistent responses. This is only possible in instances where a respondent participates in repeated survey rounds. In particular, our filter drops responses when the same respondent in two different survey rounds answers the same shadow activity questions about the same reference year with a difference of $+/-20 \%$. This filtering helps increase the reliability of survey responses used in calculating the Index.

The third section of the questionnaire asks company managers about the performance of their companies (percentage change in net sales profit, sales turnover and employment during the previous year), the education of the company owner/manager,

\footnotetext{
${ }^{9}$ Even when asked indirectly, some company owners/managers choose not to answer sensitive questions about shadow activity. One way to avoid providing truthful answers to such questions is by simply answering " 0 " to all of the shadow activity questions, suggesting that no shadow activity of any kind has taken place during the past two years. We view it as much more likely that these responses reflect avoidance of sensitive questions than truthful opinions and therefore treat these cases as non-responses, in order to minimize the downward bias in estimates of shadow activity.

${ }^{10}$ Sauka (2008) used the following approach: in the follow up survey (one year after the initial survey), respondents are 'reminded' that in the initial survey they stated that, for example, the degree of involvement in underreporting business income by 'their firm' (not by 'firms in their industry' as formulated in the initial survey) was, for example, 23\%. Each respondent is then asked whether the degree of underreporting in their companies is the same this year and if not, to what extent it has changed. The conclusion from using this method is that respondents tend to state the amount of underreporting in 'their firm' when asked about 'firms in their industry'.

${ }^{11}$ Sauka (2008) uses both face-to-face and phone interviews and concludes that willingness to talk about sensitive issues like tax evasion in Latvia does not differ significantly between the two methods.
} 
company age, industry and region. The fourth section of the questionnaire elicits company managers' opinions about why companies evade taxes.

\subsection{Calculation of the Shadow Economy Index}

The Index measures the size of the shadow economy as a percentage of GDP. ${ }^{12}$ There are three common methods of measuring GDP: the output, expenditure and income approaches. Our Index is based on the income approach, which calculates GDP as the sum of gross remuneration of employees (gross personal income) and gross operating income of firms (gross corporate income). Computation of the Index proceeds in three steps: (i) estimate the extent of underreporting of employee remuneration and underreporting of firms' operating income using the survey responses; (ii) estimate each firm's shadow production as a weighted average of its underreported employee remuneration and underreported operating income, with the weights reflecting the proportions of employee remuneration and firms' operating income in the composition of GDP; and (iii) calculate a production-weighted average of shadow production across firms.

In the first step, underreporting of firm $i$ 's operating income, $U R_{i}^{\text {Operatinghcome }}$, is estimated directly from the corresponding survey question (Q7). Underreporting of employee remuneration, however, consists of two components: (i) underreporting of salaries, or 'envelope wages' (Q11); and (ii) unreported employees (Q9). Combining the two components, firm $i$ 's total unreported proportion of employee remuneration is: ${ }^{13}$

$$
U R_{i}^{\text {EmployeeRemuneration }}=1-\left(1-U R_{i}^{\text {Salaries }}\right)\left(1-U R_{i}^{\text {Employees }}\right)
$$

In the second step, for each firm we construct a weighted average of underreported personal and underreported corporate income, producing an estimate of the unreported (shadow) proportion of the firm's production (income):

$$
\text { ShadowProportion }{ }_{i}=\alpha_{c} U R_{i}^{\text {EmployeeRemuneration }}+\left(1-\alpha_{c}\right) U R_{i}^{\text {Operatinghcome }}
$$

where $\alpha_{c}$ is the ratio of employees' remuneration (Eurostat item D.1) to the sum of employees' remuneration and gross operating income of firms (Eurostat items B.2g and B.3g). We calculate $\alpha_{c}$ for each country, $c$, in each year using data from Eurostat. Taking

\footnotetext{
${ }^{12}$ Two caveats are worth noting: (i) because we do not measure shadow activity in the state (public) sector, our estimates refer to private sector shadow activity as a percentage of private sector domestic output; and (ii) we do not attempt to measure the "black economy", i.e., the illegal goods and services.

${ }^{13}$ In deriving the formula we make the simplifying assumption that wages of unreported employees are on average equal to those of reported employees.
} 
a weighted average of the underreporting measures rather than a simple average is important to allow the Shadow Economy Index to be interpreted as a proportion of GDP. ${ }^{14}$

In the third step we take a weighted average of underreported production, ShadowProportion $_{i}$, across a representative sample of firms in country $c$ to arrive at the Shadow Economy Index for that country:

$$
\text { INDEX }_{c}^{\text {ShadowEcowmy }}=\sum_{i=1}^{N_{c}} w_{i} \text { ShadowProportion }_{i}
$$

The weights, $w_{i}$, are the relative contribution of each firm to the country's GDP, which we approximate by the relative amount of wages paid by the firm. Similar to the second step, the weighting in this final average is important to allow the Shadow Economy Index to reflect a proportion of GDP. ${ }^{15}$

As a final step, we follow the methodology of the World Economic Forum in their Global Competitiveness Report and apply a weighted moving average of INDEX ${ }_{c}^{\text {ShadowEcommy }}$ calculated from the most recent two survey rounds. There are several reasons for doing this, including: (i) it increases the amount of available information and hence precision of the Index by providing a larger sample size; and (ii) it makes the results less sensitive to the specific point in time when the survey is administered. The weighting scheme comprises two overlapping elements: (i) more weight is given to the more recent survey round as that contains more recent information (past information is “discounted"); and (ii) more weight is placed on larger sample sizes as they contain more information. ${ }^{16}$ Following the approach of the World Economic Forum, for years in which there are no previous surveys (the 2009 and 2010 results, which are based on the first survey round conducted in 2011) the Index is simply based on the one survey round. Consequently, the first two annual Index estimates (2009 and 2010) are more prone to sampling error than subsequent annual estimates, which benefit from larger samples via

\footnotetext{
${ }^{14}$ For example, suppose in an economy wages sum to 80 and corporate income 20, giving true GDP of 100. Suppose that wages are underreported by $50 \%$ and corporate income by $10 \%$ giving an official reported GDP of $40+18=58$. In this example the shadow economy is $42 \%$ of true GDP, i.e. $(100-58) / 100$. A weighted average of the two underreporting proportions accurately estimates the size of the shadow economy: $(0.8)(50 \%)+(1-0.8)(10 \%)=42 \%$. However, neither of the two underreporting proportions themselves correctly represent the size of the shadow economy (50\% and 10\%), nor does an equal weighted average: $(0.5)(50 \%)+(1-0.5)(10 \%)=30 \%$.

${ }^{15}$ For an example, consider the previous footnote's example replacing the two sources of income with two firms: a large one that produces income of 80 and a smaller one that produces income of 20 .

${ }^{16}$ For details on this procedure see the Global Competitiveness Report 2011-2012 (Box 3, p. 64), which is available at: http://www3.weforum.org/docs/WEF_GCR_Report_2011-12.pdf
} 
the moving average. To allow comparisons across countries we apply consistent methodology in calculating the Shadow Economy Index for each of the Baltic countries.

\subsection{Application of method to Baltic countries}

We apply the method described above to Estonia, Latvia and Lithuania. We use stratified random sampling to construct a sample that is representative of the population of companies. We obtain information on all active companies in each of the three Baltic countries from the Orbis database maintained by Bureau Van Dijk. For each country, we form size quintiles (using book value of assets) and take equal sized random samples from each size quintile. In total, a minimum of 500 phone interviews are conducted in each of the three Baltic countries in each survey round.

In our application of the survey, we assure the interviewee that the interviewer is from an academic institution, and that we guarantee complete confidentiality, i.e., that the company and respondent will not be named in any of the analysis or results. Such and assurance is likely to encourage more truthful responses. While such assurances are credible when the survey is conducted by an academic institution, the promise of confidentiality is less credible if the study is conducted by an agency of the government. In such cases, it may be possible and desirable for the government agency to outsource the study to a credible academic institution.

The surveys are conducted between March and April of each year and contain questions about shadow activity during the previous two years. For example, the first survey round, conducted in 2011 is used to estimate the size of the shadow economies in 2009 and 2010. The overlap of one year in consecutive survey rounds is used to validate the consistency of responses.

In the 2011 survey round we conducted a total of 591 phone interviews in Latvia, 536 in Lithuania, and 500 in Estonia. In 2012 survey round we conducted a total of 503 phone interviews in Latvia, 502 in Lithuania, and 500 in Estonia. In the 2013 survey round we conducted a total of 503 phone interviews in Latvia, 501 in Lithuania, and 500 in Estonia.

\section{Results}

\subsection{Size and components of the shadow economy in the Baltic countries}

Table 1 reports the size of the shadow economies in Latvia, Lithuania and Estonia as a percentage of GDP in the years 2009-2012. The size of the shadow economy in 2009- 
2011 is considerably higher in Latvia than Estonia and Lithuania (e.g., in 2011 the shadow economy is estimated as $30.2 \%, 18.9 \%$, and $17.1 \%$, in the three countries respectively). Latvia also stands out from the neighboring countries in that it has experienced the largest reductions in the size of its shadow economy from 2009 to 2012, in both absolute and relative terms (from $36.6 \%$ in 2009 to $21.1 \%$ in 2012). The change from 2011 to 2012 is not statistically significant for Lithuania or Estonia $(+1.1 \%$ and +0.3 accordingly), i.e., the level of shadow economy has remained approximately unchanged from 2011 to 2012 in both countries. In Latvia, however, the size of shadow economy in 2012 contracted by $9.1 \%$ of GDP compared to the level in 2011. This considerable decline in shadow activity follows a similarly notable decrease in the previous year (2011) of $7.9 \%$ of GDP. As a result, the estimates in Table 1 suggest that the size of the shadow economy in 2012 is no longer considerably higher in Latvia than in Estonia and Lithuania (21.1\% compared to $19.2 \%$ and $18.2 \%$, respectively). The differences between the three countries in 2012 are marginally statistically significant. ${ }^{17}$ Lithuania and Latvia share the similarity that the size of their shadow economies expanded from 2009 to a peak in 2010, followed by a contraction in 2011, whereas in Estonia the shadow economy seems to have followed a more consistent path of modest contractions in both 2010 and 2011.

\section{$<$ Table 1 here $>$}

The dynamics of the shadow economies in the Baltic countries during the period 2009-2012 appear to correlate with changes in macroeconomic conditions. For example, in 2009, when the Latvian shadow economy is estimated to be considerably larger than that of Estonia and Lithuania, the macroeconomic conditions in Latvia were also considerably more adverse: real GDP was falling at a rate of $17.7 \%$ p.a. compared to $14.1 \%$ in Estonia and $14.8 \%$ in Lithuania, and unemployment in Latvia was $17.3 \%$ compared to $13.8 \%$ in Estonia and $13.7 \%$ in Lithuania. In 2012, the shadow economies are estimated as being more similar in size and the macroeconomic conditions also display less disparity: real GDP is growing at a rate of 5.6\% p.a. in Latvia, 3.2\% in Estonia and $3.6 \%$ in Lithuania, and unemployment in Latvia is $14.9 \%$ compared to $9.8 \%$ in Estonia and $13.2 \%$ in Lithuania. ${ }^{18}$ These observations could, in part, reflect a tendency for shadow

\footnotetext{
${ }^{17}$ The p-values for independent samples t-tests of the differences in the mean level of shadow economy for the pairs Latvia-Lithuania and Latvia-Estonia are 0.08 and 0.33 , respectively.

${ }^{18}$ IMF World Economic Outlook 2010, 2012 and 2013.
} 
sector activity to increase during difficult times in the business environment; however, our analysis does not provide any evidence of causality between macroeconomic conditions and the level of shadow economy. In fact, due to our relatively short time-series dimension (2009-2012) we do not even formally test for correlation between the size of the shadow economy and macroeconomic conditions.

The differences across the three countries are consistent with various countryspecific factors. For example, Estonia was the first of the three countries to enter the Eurozone on 1 January 2011. Estonia is also the only one of the three countries to show a decline in the estimated size of its shadow economy in 2010, consistent with need for greater transparency and legality. Similarly, Latvia joined the Eurozone on 1 January 2014 , and it is the only country to show a decline in the size of its shadow economy in the last year of our sample, 2012. Furthermore, Latvia was the only country in our sample to receive a substantial bailout package during the recent crisis from a conglomerate of international organizations (the European Union, the International Monetary Fund, and others). The financial assistance was provided in exchange for the Latvian government's commitment to stringent austerity measures and a series of reforms, including deliberate policy measures targeting the shadow economy. As a result, the Latvian government set up a high-level working group led by the Ministry of Finance State Secretary and comprising members from various ministries, the Treasury, Latvian Federal Police, State Revenue Service, the Corruption Prevention and Combatting Bureau, as well as experts from academia, the Bank of Latvia and the Central Statistical Bureau. The key outcome from the working group was a package of 66 different policy actions to combat the informal economy. All but three of proposed policy actions were approved and implemented at different points in time during 2010-2013. Some involved changes to legislation, others were simply programs or actions undertaken by various ministries and/or government organizations/bureaus, working independently or in collaboration. Thus, Latvia experienced the strongest deliberate policy efforts aimed at reducing shadow sector activity. Consistent with notion that the policy measures were effective, Table 1 suggests Latvia experienced the most significant decline in the size of its shadow economy from 2010 to 2012. Finally, the significant transshipment activities between Russia and Western Europe may contribute to the shadow economies in the Baltic countries. About $40 \%$ of Russian exports to non-Baltic EU member states are transported through the Baltic countries (Laurila, 2003; Kovács and Spens, 2006). Of the total cargo carried in the Baltic Sea serving the East-West corridor, Estonian ports handle 12\%, 
Latvian ports 28\% and Lithuanian ports 9\% (Laurila, 2003; Kovács and Spens, 2006). The higher transshipment volumes in Latvia, followed by Estonia and then Lithuania, are consistent with our estimates suggesting that in all sample years the size of the shadow economy is largest in Latvia, followed by Estonia and then Lithuania. ${ }^{19}$

The dynamics of the shadow economy estimates, shown in Table 1, are also largely consistent with estimates from other indirect methods. For example, Schneider (2013) uses an indirect latent variable method (MIMIC) and obtains the same dynamics for Latvia (an increase from 2009 to 2010 and two subsequent years of decreases). Schneider's estimates also concur with the dynamics of the Index for Estonia and Lithuania, other than the statistically insignificant changes from 2011 to 2012.

Although the dynamics are similar, the absolute size of the shadow economies estimated in our study differs from those in Schneider (2013). For example, taking the most recent available year (2012) our estimates suggest the shadow economy in Estonia, Latvia and Lithuania is $19.2 \%, 21.1 \%$ and $18.2 \%$, respectively, whereas Schneider (2013) estimates the corresponding numbers to be $28.2 \%, 26.1 \%$ and $28.5 \%$. The difference of 5$10 \%$ in the estimates from the two different methods could be due to a number of reasons. First, with indirect methods such as MIMIC it is difficult to define exactly what part of unobserved production is estimated. Therefore, the method applied by Schneider (2013) may effectively measure different components of unobserved production, despite using the same definition of 'shadow economy'. A second reason why our estimates are lower than those of Schneider (2013) could be the tendency of survey-based methods to underestimate the size of the shadow economy, and/or the tendency for indirect methods to overestimate the size of the shadow economy. Indeed, other papers point out that survey-based methods tend to produce lower estimates than indirect methods (e.g., Feld and Schneider, 2010; Williams, 2013; Buehn and Schneider, 2013). However, there is no consensus as to whether the difference is due to survey-based methods underestimating the size of the shadow economy, indirect methods producing inflated estimates, or both (Williams, 2013). Feld and Schneider (2010, p.133) suggest that both overestimation and underestimation play a role: "the estimates from the MIMIC approach can be regarded as

\footnotetext{
${ }^{19}$ The patterns in transhipment volumes and shadow economy levels also mirror the proportions of ethnic Russians in each of the three countries $28.0 \%$ in Latvia, $25.6 \%$ in Estonia, and $4.9 \%$ in Lithuania, as reported by Vadi and Jaakson (2011)). It is possible that ethnic Russians may feel less satsfied with the government, which can in turn influence their tax evasion behavior. In later subsections we investigate differences across the countries with respect to attitudes and satisfaction with the govement.
} 
the upper bound of the shadow economy, and the estimates obtained from the survey approach provide its lower bound."

Other widely-used methods for estimating the size of a shadow economy include macro methods such as the electric consumption approach and the currency deposit ratio approach. To the best of our knowledge the most recent application of these methods to the Baltic countries is Feige and Urban (2008) for the period 1990-2001. ${ }^{20}$ The period covered by their study does not overlap with ours (2009-2012), and therefore comparisons from the two studies are suggestive at best, keeping in mind that the sizes of shadow economies vary through time. ${ }^{21}$ Using a modified electric consumption approach (MEC) / currency deposit ratio approach (CDM) Feige and Urban estimate the size of the shadow economies in Estonia, Latvia and Lithuania as 14.3\%/21.6\%, 19.4\%/31.6\%, and $19.7 \% / 29.0 \%$, respectively. The corresponding estimates from our method for the closest available year (2009) are 20.2\%, 36.6\%, and 17.7\%. Our estimates are within the range given by MEC/CDM for Estonia, above the MEC/CDM estimates for Latvia and below the MEC/CDM estimates for Lithuania. Thus, unlike the comparison with MIMIC, estimates from our method are not consistently higher or lower than those obtained from electric consumption and currency deposit ratio methods. The differences between our estimates and the MEC/CDM estimates are partly due to the different sample periods, but also partly due to estimation error stemming from misspecification and violated assumptions in the macro models. Feige and Urban (2008) find that the MEC/CDM estimates can be highly inconsistent with one another, suggesting their estimation errors can be large and preclude confidence in the estimates.

Finally, we can also compare our estimates with those of other survey-based methods. The European Commission's Special Eurobarometer (No. 284, “Undeclared work in the European Union") is based on approximately 1,000 face-to-face surveys in each of $27 \mathrm{EU}$ member states during 2007. ${ }^{22}$ A key difference between the Eurobarometer (2007) survey and our method is the way in which the sensitive questions are framed. The Eurobarometer questionnaire asks questions directly about individuals' undeclared work/income, whereas our questionnaire uses the indirect approach to illicit more truthful answers, asking instead about practices in other companies within the industry. The

\footnotetext{
${ }^{20}$ For earlier estimates of the shadow economies in the Baltic countries using the electric consumption and currency demand approaches see Schneider and Enste (2000).

${ }^{21}$ Estimates from Schneider et al. (2010) and Scheider (2013) suggest that the sizes of the Baltic shadow economies in 2010 are all within $4 \%$ of their levels in the year 2000.

${ }^{22}$ Williams (2008) provides additional analysis of the Eurobarometer survey data for Eastern European countries.
} 
Eurobarometer survey asks employed individuals "did your employer pay you all or part of your income in the last 12 months in this way (undeclared 'envelope' wages)?" (QB16), and those that answer "yes" are asked what percentage of their income is paid in this form (QB17). The percentage of employed individuals admitting they receive envelope wages is $8 \%$ in Estonia, $17 \%$ in Latvia and $11 \%$ in Lithuania. Multiplying the percentages together (QB16 and QB17) gives a rough estimate of the proportion of total gross wages that are not declared: $2.5 \%$ in Estonia, $7.9 \%$ in Latvia and 5.3\% in Lithuania. The authors of Eurobarometer (2007) acknowledge that "the relatively low values measured in Southern Europe and many Eastern European states are surprising” (p.19), pointing out that these are sensitive issues and due to the direct nature of the questions the estimates "should be interpreted as the lower limit" (p.18). The question about envelope wages in our questionnaire (Q11) is different in that it asks for an estimate of the percentage of true salaries in the industry that is not declared (paid in the form of envelope wages). Our results for 2009 suggest that on average envelope wages are $19.5 \%$ of total wages in Estonia, 34.0\% in Latvia, and 15.0\% in Lithuania. Our estimates of undeclared wages are much higher than those in the Eurobarometer study. We attribute the bulk of the difference in estimates to the various techniques that we employ to maximize the truthfulness of responses: asking questions in an indirect form, gradually working up to the sensitive questions rather than starting with them, framing the survey as a study of satisfaction with government rather than a survey of shadow economy, assurances of confidentiality, and an academic affiliation with no connection to government authorities.

$<$ Figure 2 here >

In contrast to indirect methods, our approach is able to provide more detailed information on the components and determinants of the shadow economy, which we turn to now. Figure 2 illustrates the relative size of the components of the shadow economy in each of the three countries. Envelope wages constitute a large proportion of the shadow economies in all three countries: they account for $52.3 \%$ of the shadow economy in Estonia, $42.9 \%$ in Latvia and $39.3 \%$ in Lithuania. The next largest component is unreported business income, which makes up between $28.5 \%$ and $42.7 \%$ of the shadow economy depending on the country. Finally, unreported employees make up the 
remainder, and account for between $17.6 \%$ and $19.2 \%$ of the shadow economy in each of the countries.

\subsection{Determinants of shadow activity}

In this subsection we examine the factors that influence firms' decisions to participate in the shadow economy. The literature on tax evasion identifies two main groups of factors that affect the decision to evade taxes and participate in the shadow economy. The first set emerges from rational choice models of the decision to evade taxes (e.g., Allingham and Sandmo, 1972; Yitzhaki, 1974). ${ }^{23}$ In such models individuals or firms weigh up the benefits of evasion in the form of tax savings against the probability of being caught and the penalties that they expect to receive if caught. The higher the probability of being caught or the more severe the consequences, the less attractive it is to evade taxes. Therefore the decision to underreport income and participate in the shadow economy is affected by the detection rates, the size and type of penalties, firms' attitudes towards risk-taking and so on.

To measure this first set of factors the survey includes questions about the likelihood of being caught for underreporting business profits, number of employees, salaries, as well as involvement in bribery. We also asked company managers to evaluate potential consequences for the firm if it were caught for deliberate misreporting. Slemrod (2007, p. 38) points out that "there has been no compelling empirical evidence addressing how noncompliance is affected by the penalty for detected evasion, as distinct from the probability that a given act of noncompliance will be subject to punishment." The advantage of micro-level survey-based approach is that we are able to separate the probability of detection from the penalty for detected evasion and estimate their individual impacts on the propensity for a firm to evade taxes.

Empirical studies find that the actual amount of tax evasion is considerably lower than predicted by rational choice models. For example, Feld and Frey (2002) point out that at with US levels of detection probability and penalties rational choice models would predict that everyone should evade taxes. Alternatively, to explain the actual level of tax evasion in the US using a simple rational choice model, people must have Arrow-Pratt measures of risk aversion of more than 30, whereas existing field evidence suggests a range of between one and two. The difference between the relatively high levels of tax

\footnotetext{
${ }^{23}$ For good surveys of this literature see Andreoni et al. (1998), Sandmo (2005) and Slemrod (2007).
} 
evasion predicted by rational choice models and the relatively low levels observed in practice is often attributed to the second, broader, set of tax evasion determinants attitudes and social norms (see Andreoni et al. (1998) and Slemrod (2007) for a review). These factors include perceived justice of the tax system, i.e., attitudes about whether the tax burden and administration of the tax system are fair, attitudes about how appropriately taxes are spent and how much firms trust the government. Finally, tax evasion is also influenced by social norms such as ethical values and moral convictions, as well as fear of feelings of guilt and social stigmatization if caught.

We measure two aspects of the second group of tax evasion determinants, namely attitudes towards the government and tax system, and social norms / tax morale. We measure firms' attitudes towards the government and the tax system using four questions about their satisfaction with the State Revenue Service, the government's tax policy, business legislation and the government's support for entrepreneurs (see Q1-Q4 in Appendix A). We measure social norms using two questions about the extent to which tax evasion and bribery are considered tolerated behaviors (see Q5-Q6 in Appendix A).

All of the factors discussed above (detection rates, the size and type of penalties, attitudes and social norms) are likely to differ across company characteristics such as country, region, sector, size, and age of firm. These company characteristics may also influence a company's propensity to engage in shadow activity and therefore we include these firm characteristics as explanatory variables when testing for the determinants of shadow activity.

We use regression analysis to identify the factors that influence firms' involvement in the shadow economy. The regression results are reported in Table 2, using data from the most recent survey round (2013). The results from earlier survey rounds are similar. ${ }^{24}$ Model 1 includes most of the possible influential factors and dummy variables for Estonian and Lithuanian firms. Model 2 replaces the country level dummy variables with country*region dummy variables. Model 3 drops the statistically insignificant determinants (other than tolerance of tax evasion, which is an important control variable).

\footnotetext{
${ }^{24}$ The regression results using data from earlier survey rounds are not reported here to save space, but are available from the authors upon request.
} 
The country dummy variables suggest that the size of the shadow economy is slightly smaller in Estonia and Lithuania relative to Latvia after controlling for a range of explanatory factors, although the coefficients are not statistically significant. Tolerance towards tax evasion is positively associated with the firm's stated level of income/wage underreporting, i.e., company managers that view tax evasion as a tolerated behavior tend to engage in more informal activity. The measures of tolerance also serve the important role of controlling for possible understating of the extent of shadow activity (untruthful responses) due to the sensitivity of the topic. ${ }^{25}$

The regression coefficients indicate that the effect of perceived detection probabilities and penalties on the tendency for firms to engage in deliberate misreporting is consistent with the predictions of rational choice models (e.g., Allingham and Sandmo, 1972; Yitzhaki, 1974), i.e., the higher the perceived probability of detection and the larger the penalties, the lower the amount of tax evasion and misreporting. The effect of detection probability in particular stands out as being a particularly strong deterrent of shadow activity. This evidence suggests a possible policy tool for reducing the size of the shadow economies, namely increasing the probability of detection of misreporting. This could be done via an increased number of tax audits, whistle-blower schemes that provide incentives to report information to authorities about non-compliant companies, and investment in tax evasion detection technology.

The regression results also indicate that a firm's satisfaction with the tax system and the government is negatively associated with the firm's involvement in the shadow economy, i.e. dissatisfied firms engage in more shadow activity, satisfied firms engage in less. This result is consistent with previous research on tax evasion, and offers an explanation of why the size of the shadow economy is slightly larger in Latvia than in Estonia and Lithuania; namely that Latvian firms engage in more shadow activity because they are more dissatisfied with the tax system and the government. ${ }^{26}$ Analyzing each of

\footnotetext{
${ }^{25}$ For example, consider two firms that underreport income/wages by $40 \%$ each, but the first operates in an environment in which tax evasion is considered highly unethical and is not tolerated, whereas the second operates in an environment in which tax evasion is relatively tolerated. The first firm might state that its estimate of underreporting is around 20\% (a downward biased response due to the more unethical perception of tax evasion) whereas the second firm might answer honestly that underreporting is around $40 \%$. This example illustrates that failure to control for the sensitivity of tax evasion (proxied here by tolerance) can lead to biased comparisons.

${ }^{26}$ The average satisfaction score in each of the four areas (State Revenue Service, the government's tax policy, business legislation and the government's support for entrepreneurs) is lower for Latvian company
} 
the four measures of satisfaction separately we find that shadow activity is most strongly related to dissatisfaction with business legislation and the State Revenue Service, followed by the government's tax policy and support for entrepreneurs.

Another strong determinant of involvement in the shadow economy is firm size, with smaller firms engaging in more shadow activity than larger firms. Firm age, although not statistically significant, suggests that younger firms engage in more shadow activity than older firms. A possible explanation for these two relations is that small, young firms use tax evasion as a means of being competitive against larger and more established competitors. The sector dummy variables are not statistically significant but suggest that firms in the construction sector tend to engage in more shadow activity. There is no evidence of an association between shadow activity and the average wage paid by a firm or a firm's change in profits (or employees or turnover).

\subsection{Company managers' attitudes regarding shadow activities}

In surveying company managers we also elicited opinions about various aspects of the shadow economies in the Baltic countries. We believe that these data might be useful to policy makers, at least as complementary information. More specifically, we asked a number of questions about companies' motivation to participate in tax evasion. Company managers were offered various alternatives and asked to assess those on a 1-7 scale, where ' 1 ' represents 'completely agree' and ' 7 ' represents 'completely disagree'. The results from the most recent (2013) survey round are summarized in Figure 2.

$<$ Figure 2 here >

Latvian companies are more inclined to emphasize tax evasion as a possible tool to ensure competitiveness (and survival) of the firm. For example, in response to the statement "to ensure successful performance of a company (including survival) it is much more important to have an appropriate product than to evade taxes", both Estonian and Lithuanian company managers reported more towards 1 'completely agree' (1.6 and 1.4, respectively), whereas the average response from Latvian company managers is 3.0. Also, Latvian company managers, relative to Estonian and Lithuanian managers, tend to agree with the statement that evading taxes is necessary to survive (response scores of 3.9 in 
Latvia, 5.1 Lithuania and 5.2 in Estonia). Furthermore, Latvian managers are more inclined to link higher levels of tax evasion with lower past performance. Finally, managers from all three Baltic countries seem to agree that performance of their companies very much depends on the economic situation in the country.

\section{Conclusions}

We develop a method of estimating the size of a shadow economy using surveys of company managers - those that are most likely to know how much business income and wages go unreported. The key features of our method are: (i) employing a range of survey design features shown in previous studies to help illicit truthful answers (e.g., Gerxhani, 2007; Kazemier and van Eck, 1992; Hanousek and Palda, 2004); and (ii) exploiting precise economic relations between components of GDP to go from survey item responses to an estimate of the size of a shadow economy as a percentage of GDP. Our shadow economy index combines estimates of misreported business income, unregistered or hidden employees, as well as unreported 'envelope' wages. Our method can be applied to a large number of countries; its only data requirements are: (i) a list of local companies with contact details (available from databases such as Bureau Van Dijk's Orbis, or national business registries); and (ii) national accounts estimates of employees' remuneration and gross operating income of firms (available from national statistics bureaus or agencies such as Eurostat).

The main advantages of our method of measuring the shadow economy, compared to macro methods and latent variable methods, are as follows. First, our method produces micro-level (firm-level) estimates, which can be used to examine how involvement in the shadow economy varies across firms. Such information can be very useful to policymakers and regulators in targeting problematic sectors or types of firms, or in testing cross-sectional theories about companies' involvement in the shadow economy. Second, our method is precise about what parts of observed or unobserved production are included in the estimates. As a result, estimates of the shadow economy using our method may be useful in adjusting official GDP measures to account for the shadow economy. This is an important area for future research, given the widespread use of GDP estimates in measuring the success or failure of economic policies, constructing ratios such as budget deficit to GDP and public sector debt to GDP, which determine outcomes such as international economic aid and currency union accession, calculating the level of 
contributions and subsidies in economic unions such as the European Union, and in crosscountry comparisons of economic development and welfare.

A downside of our method is that it is more costly and time-consuming (than macro methods) to collect the necessary inputs to the calculation. Furthermore, to the extent that some respondents will provide untruthful responses about the shadow economy, despite assurances of confidentiality and various surveying techniques designed to illicit truthful answers, the shadow economy estimates will understate the true size of the shadow economy.

We illustrate our method by applying it to the Baltic countries in three successive years, forming a short panel of shadow activity estimates. Our results indicate some interesting cross-sectional differences and dynamics in the size of the Baltic shadow economies. The size of the Latvian shadow economy as a proportion of GDP has seen a considerable contraction from 2009 to 2012. In contrast the sizes of the shadow economies in Estonia and Lithuania have remained more stable with modest fluctuations during the past four years. In light of the detrimental long-term effects of having a large shadow economy, the contraction in the Latvian shadow economy is an encouraging sign. Despite its significant decrease, the size of the shadow economy in Latvia remains somewhat larger than in neighboring Lithuania and Estonia, highlighting the importance of continuing policy efforts to minimize shadow sector activities.

The dynamics of our shadow economy estimates are consistent with other studies that use different estimation methods, e.g., Schneider (2013). This serves as an indirect validation of the estimates. An advantage of our approach is that we are able to provide more detailed information on the components and determinants of the shadow economy. For example, the micro-level evidence suggests that the decline in the size of the shadow economy in Latvia has been driven mainly by decreases in underreporting of business profits, followed by decreasing envelope wages. The retail, services and construction sectors have seen the most significant improvements. Large firms have also experienced a considerable improvement in the amount of misreporting and tax evasion. The increasing satisfaction of Latvian company managers with the State Revenue Service (SRS) is likely to account for some of the reduction in the level of the Latvian shadow economy. A series of policy actions targeting the shadow economy in Latvia are likely to have contributed to the decline in the size of the Latvian shadow economy.

Finally, we illustrate one the main comparative advantages of our method of measuring the shadow economy - the micro-level estimates - by testing the cross- 
sectional determinants of a firm's propensity to participate in the shadow economy. We find that firms that are dissatisfied with the tax system or the government tend to engage in more shadow activity. This result is consistent with previous research on tax evasion, and has implications for policies to reduce the size of the shadow economy. We also find that smaller, younger firms engage in proportionally more shadow activity than larger, older firms, consistent with the anecdotal evidence that tax evasion is used by firms to gain a competitive edge, and that having an edge is important in competing in an established market. Finally, the level of tax evasion and deliberate misreporting among Baltic companies is responsive to the perceived probabilities of being caught and to the expected penalties for being caught, consistent with rational expectations models of tax evasion. In particular, companies that perceive the probability of being caught as being higher tend to engage in less shadow activity.

Our findings suggest a number of approaches for policymakers to reduce the size of the shadow economies in countries similar to the new EU member states to which we applied our method. First, reducing dissatisfaction with the tax system is likely to decrease the size of the shadow economies. Addressing this issue could involve actions such as making tax policy more stable (less frequent changes in procedures and tax rates), making taxes more 'fair' from the perspective of businesses and employees, and increasing the transparency with which taxes are spent. Second, increasing the probability of detection is expected to reduce shadow activity. This could be achieved via an increased number of tax audits, whistle-blower schemes that provide incentives to report information to authorities about non-compliant companies, and investment in tax evasion detection technology.

\section{Acknowledgements}

The authors thank the Centre for Sustainable Business at SSE Riga powered by SEB for the financial support, SKDS for data collection, the company managers that agreed to participate in interviews, and an anonymous referee for comments that improved the paper. 


\section{ENTREPRENEURS' SATISFACTION WITH GOVERNMENT POLICY / INFORMAL ENTREPRENEURSHIP IN THE BALTIC COUNTRIES}

My name is ... from the Stockholm School of Economics in Riga. We are conducting a survey aimed at understanding entrepreneurs' satisfaction with government policy in Latvia (Lithuania, Estonia). The main interest of the study is to find out to what extent entrepreneurs are happy with the government's activity as well as how government policy influences entrepreneurial behavior, including tax avoidance.

I would like to emphasize that we are only interested in your expert opinion and in no way are we indicating, for instance, that your company is involved in any type of tax avoidance activities.

The interview will last approximately 15 minutes. We guarantee $100 \%$ confidentiality as neither your name nor your company's name will appear in the data analysis. Data will be analyzed using a computer program without any reference to the data source. If you are interested, we can also send you the summary of the survey results once the survey is complete.

\section{If respondent hesitates or says 'no':}

This survey is very important to foster the knowledge about the entrepreneurship in Latvia (Lithuania, Estonia). By participating in this survey you are helping to improve such knowledge. All your answers will be $100 \%$ confidential and no one will be able to track you or your company. Moreover we are interested in your expert opinion and what you say will be attributed to the industry or your competitors, not your firm.

\section{$\underline{\text { External influences }}$}

1. Please evaluate your satisfaction with the performance of the State Revenue Service in Latvia (Lithuania, Estonia) with regards to tax administration in 2012.

\begin{tabular}{|c|c|c|c|c|}
\hline 1 & 2 & 3 & 4 & 5 \\
\hline $\begin{array}{c}\text { Very } \\
\text { unsatisfied }\end{array}$ & Unsatisfied & $\begin{array}{c}\text { Neither } \\
\text { satisfied nor } \\
\text { unsatisfied }\end{array}$ & Satisfied & $\begin{array}{c}\text { Very } \\
\text { satisfied }\end{array}$ \\
\hline
\end{tabular}

2. Please evaluate your satisfaction with the government's tax policy in Latvia (Lithuania, Estonia) in 2012.

\begin{tabular}{|c|c|c|c|c|}
\hline 1 & 2 & 3 & 4 & 5 \\
\hline $\begin{array}{c}\text { Very } \\
\text { unsatisfied }\end{array}$ & Unsatisfied & $\begin{array}{c}\text { Neither } \\
\text { satisfied nor } \\
\text { unsatisfied }\end{array}$ & Satisfied & $\begin{array}{c}\text { Very } \\
\text { satisfied }\end{array}$ \\
\hline
\end{tabular}

3. Please evaluate your satisfaction with the quality of business legislation in Latvia (Lithuania, Estonia) in 2012.

\begin{tabular}{|c|c|c|c|c|}
\hline 1 & 2 & 3 & 4 & 5 \\
\hline Very & Unsatisfied & Neither & Satisfied & Very \\
\hline
\end{tabular}




\begin{tabular}{|c|c|c|c|c|}
\hline unsatisfied & $\begin{array}{c}\text { satisfied nor } \\
\text { unsatisfied }\end{array}$ & satisfied \\
\hline
\end{tabular}

4. Please evaluate your satisfaction with the government's support to entrepreneurs in Latvia (Lithuania, Estonia) in 2012.

\begin{tabular}{|c|c|c|c|c|}
\hline 1 & 2 & 3 & 4 & 5 \\
\hline $\begin{array}{c}\text { Very } \\
\text { unsatisfied }\end{array}$ & Unsatisfied & $\begin{array}{c}\text { Neither } \\
\text { satisfied nor } \\
\text { unsatisfied }\end{array}$ & Satisfied & $\begin{array}{c}\text { Very } \\
\text { satisfied }\end{array}$ \\
\hline
\end{tabular}

5. Tax avoidance is tolerated behavior in Latvia (Lithuania, Estonia).

\begin{tabular}{|c|c|c|c|c|}
\hline 1 & 2 & 3 & 4 & 5 \\
\hline $\begin{array}{c}\text { Completely } \\
\text { disagree }\end{array}$ & Disagree & $\begin{array}{c}\text { Neither } \\
\text { agree nor } \\
\text { disagree }\end{array}$ & Agree & $\begin{array}{c}\text { Completely } \\
\text { agree }\end{array}$ \\
\hline
\end{tabular}

6. Bribing is tolerated behavior in Latvia (Lithuania, Estonia).

\begin{tabular}{|c|c|c|c|c|}
\hline 1 & 2 & 3 & 4 & 5 \\
\hline $\begin{array}{c}\text { Completely } \\
\text { disagree }\end{array}$ & Disagree & $\begin{array}{c}\text { Neither } \\
\text { agree nor } \\
\text { disagree }\end{array}$ & Agree & $\begin{array}{c}\text { Completely } \\
\text { agree }\end{array}$ \\
\hline
\end{tabular}

\section{Government policy and amount of informal business}

7. Please estimate the approximate degree of underreporting business income by firms in your industry in 2012:

Firms underreported business income by approximately $\%$ in 2012.

8. Please estimate the approximate degree of underreporting business income by firms in your industry in the previous year (2011):

Firms underreported business income by approximately $\%$ in 2011.

9. Please estimate the approximate degree of underreporting number of employees by firms in your industry in 2012:

Firms underreported approximately $\%$ of the actual number of employees in 2012.

10. Please estimate the approximate degree of underreporting number of employees by firms in your industry in the previous year (2011)

Firms underreported approximately $\%$ of the actual number of employees in 2011.

11. Please estimate the approximate degree of underreporting salaries paid to employees by companies in your industry in 2012 (for instance, if in reality an employee receives EUR 400, but the reported salary is EUR 100, then underreporting is 75\%; if EUR 400 and EUR 200, then underreporting is 50\%):

Firms underreported actual salaries by approximately $\%$ in 2012.

12. Please estimate the approximate degree of underreporting salaries paid to employees by companies in your industry in 2011.

Firms underreported actual salaries by approximately __ \% in 2011. 
13. On average, approximately what percent of revenue (turnover) did firms in your industry pay in unofficial payments to 'get things done' in 2012?

In 2012 firms paid approximately $\%$ of their revenue in order to get things done.

14. On average, approximately what percent of revenue (turnover) did firms in your industry pay in unofficial payments to 'get things done' in 2011?

In 2011 firms paid approximately $\%$ of their revenue in order to get things done.

15. When other firms in your industry do business with the government, approximately how much of the contract value would firms typically offer in unofficial payments to 'secure' the contract? (year 2012) $\%$

16. For a typical company in your industry, what would you say is the approximate probability (0-100\%) of being caught if the company were to:

(i) underreport its business income? $\%$

(ii) underreport its number of employees? $\%$

(iii) underreport the amount it pays to employees in salaries? $\%$

(iv) make unofficial payments to 'get things done'? $\%$

17. If a company in your industry were caught for deliberate misreporting, what would typically be the consequence to that company?

\begin{tabular}{|c|c|c|c|c|}
\hline Nothing serious & A small fine & $\begin{array}{c}\text { A serious fine that } \\
\text { would affect the } \\
\text { competitiveness } \\
\text { of the company }\end{array}$ & $\begin{array}{c}\text { A serious fine } \\
\text { that would put } \\
\text { the company at } \\
\text { risk of } \\
\text { insolvency }\end{array}$ & $\begin{array}{c}\text { The company } \\
\text { would be forced } \\
\text { to cease } \\
\text { operations }\end{array}$ \\
\hline 1 & 2 & 3 & 4 & 5 \\
\hline
\end{tabular}

\section{Company}

18. What is the approximate percentage change in your net sales profit, sales turnover and total employment in 2012 compared to 2011?

\begin{tabular}{|l|l|l|l|}
\hline & 1 Net sales profit & 2. Sales turnover & 3 Total employment \\
\hline $\begin{array}{l}\text { Change (increase or } \\
\text { decrease in \%) as } \\
\text { compared to 2011. }\end{array}$ & & & \\
For example: $+20 \%$, & & \\
$-15 \%, 0$ (no change) & & & \\
\hline
\end{tabular}

19. Do you consider that businesses such as yours contribute to the growth of the Latvian (Estonia, Lithuanian) economy and society in general?

\begin{tabular}{|c|c|c|c|c|}
\hline 1 & 2 & 3 & 4 & 5 \\
\hline $\begin{array}{c}\text { Yes, to a } \\
\begin{array}{c}\text { very large } \\
\text { extent }\end{array}\end{array}$ & $\begin{array}{c}\text { Yes, to a } \\
\text { large extent }\end{array}$ & $\begin{array}{c}\text { Yes, to some } \\
\text { extent }\end{array}$ & $\begin{array}{c}\text { Yes, but } \\
\text { very little }\end{array}$ & No \\
\hline
\end{tabular}


20. Has your company been involved in sponsorship for social needs (for example, hospitals, social organizations, sports) during 2012? If so, approximately what percentage of your annual after-tax profits was spent on sponsorship during 2011? $\%$ (0-100 from annual profits after taxes)

21. How many years of business management experience do you have? years

22. In which year did your company start operation?

Year

23. What is the main activity (i.e. sector) that your company is engaged in?

Manufacturing

Wholesale

Retail

Services (please specify

Construction

Other, please specify

24. What is the highest level of education you have attained?

$\square$ Primary school

$\square$ Vocational education

Vocational secondary education

Secondary school education

Undergraduate (bachelor's degree or equivalent)

Engineering degree

Master's degree

$\mathrm{PhD}$ degree

Other, please specify

25. What was the operating profit of your company in 2012?

EUR

26. How many employees are currently employed in your company (full time equivalent, including you)? employees

27. Approximately what was the average reported salary in your company in 2012? EUR / month

28. In which region does your company conduct most of its business?

(note: different list of regions for Lithuania and Estonia)

Rīga

Kurzeme

Vidzeme

Zemgale

Latgale 


\section{$\underline{\text { Attitudes }}$}

29. Do you agree that $(1=$ completely agree; $7=$ completely disagree $)$ :

\begin{tabular}{|l|l|l|l|l|l|l|l|}
\hline $\begin{array}{l}\text { Firms in your industry tend to evade taxes more if } \\
\text { they are having relatively bad times (for instance, } \\
\text { decrease in profits or turnover in comparison to } \\
\text { previous years) }\end{array}$ & 1 & 2 & 3 & 4 & 5 & 6 & 7 \\
\hline $\begin{array}{l}\text { Entrepreneurs in your industry evade taxes } \\
\text { because this is the only way to survive. }\end{array}$ & 1 & 2 & 3 & 4 & 5 & 6 & 7 \\
\hline $\begin{array}{l}\text { Whenever possible, entrepreneurs will try to } \\
\text { decrease their business costs, which also includes } \\
\text { evading taxes, regardless of how their company } \\
\text { performs. }\end{array}$ & 1 & 2 & 3 & 4 & 5 & 6 & 7 \\
\hline $\begin{array}{l}\text { Whenever possible, entrepreneurs will try to } \\
\text { decrease their business costs, which also includes } \\
\text { evading taxes, regardless of the nature of the } \\
\text { Government's entrepreneurship policy in Latvia } \\
\text { (state support, tax legislation, etc.) }\end{array}$ & 1 & 2 & 3 & 4 & 5 & 6 & 7 \\
\hline $\begin{array}{l}\text { Entrepreneurs in Latvia trust the Government, and } \\
\text { believe that their tax money is spent appropriately. }\end{array}$ & 1 & 2 & 3 & 4 & 5 & 6 & 7 \\
\hline $\begin{array}{l}\text { Tax evasion is primarily entrepreneurs' response } \\
\text { to what they believe are incorrect actions by the } \\
\text { State with regard to promoting entrepreneurship. }\end{array}$ & 1 & 2 & 3 & 4 & 5 & 6 & 7 \\
\hline $\begin{array}{l}\text { To ensure successful performance of a company } \\
\text { (including survival) it is much more important to } \\
\text { have appropriate product and business strategies } \\
\text { than to evade taxes. }\end{array}$ & 1 & 2 & 3 & 4 & 5 & 6 & 7 \\
\hline $\begin{array}{l}\text { Performance of your company very much depends } \\
\text { on the economic situation in the country: your } \\
\text { company performs considerably better during } \\
\text { economic growth, but during economic recession } \\
\text { performance gets considerably worse. }\end{array}$ & 1 & 2 & 3 & 4 & 5 & 6 & 7 \\
\hline $\begin{array}{l}\text { Performance of companies in your industry is very } \\
\text { much influenced by their choice to pay or evade } \\
\text { taxes: by evading taxes firms in your industry } \\
\text { considerably increase their profits. }\end{array}$ & 1 & 2 & 3 & 4 & 5 & 6 & 7 \\
\hline
\end{tabular}

Thank you. 


\section{References}

Ahumada, H.; Alvaredo, F.; Canavese, A., 2007. The monetary method and the size of the shadow economy: A critical assessment. Review of Income and Wealth 53(2), 363-371.

Aidis, R.; Van Praag, M., 2007. Illegal entrepreneurship experience: Does it make a difference for business performance and motivation? Analyzing the effects of illegal entrepreneurship experience in Lithuania. Journal of Business Venturing 22(2), 283-310.

Allingham, M.G.; Sandmo, A., 1972. Income tax evasion: A theoretical analysis. Journal of Public Economics 1, 323-338.

Andreoni, J.; Erard, B.; Feinstein, J., 1998. Tax compliance. Journal of Economic Literature 36, 818-860.

Bajada, C.; Schneider F., 2005. Size, causes and consequences of the underground economy: An international perspective (Ashgate Publishing Company: Aldershot).

Baumol, W., 1990. Entrepreneurship: Productive, unproductive and destructive. Journal of Political Economy 98, 893-921.

Breusch, T., 2005a. The Canadian underground economy: An examination of Giles and Tedds. Canadian Tax Journal 53(2), 367-391.

Breusch, T., 2005b. Estimating the underground economy using MIMIC models. Unpublished manuscript.

Buehn, A.; Schneider, F., 2013. Estimating the size of the shadow economy: Methods, problems and open questions. Unpublished manuscript.

Cagan, P., 1958. The demand for currency relative to the total money supply. Journal of Political Economy 66, 302-328.

Clotefelter, C.T., 1983. Tax evasion and tax rates: An analysis of individual returns. Review of Economic Statistics 65, 363-373.

Dell'Anno, R., 2007. The shadow economy in Portugal: An analysis with the MIMIC approach. Journal of Applied Economics 10, 253-277.

Eurobarometer, 2007. Special Eurobarometer 284: Undeclared Work in the European Union (European Commission: Brussels).

Fairlie, R., 2002. Drug dealing and legitimate self- employment. Journal of Labour Economics 20(3), 538-567.

Feige, E.L., 1979. How big is the irregular economy? Challenge 22(5), 5-13. 
Feige, E.L., 1986. A re-examination of the underground economy in the United States. IMF Staff Papers 33(4), 768-781.

Feige, E.L., 1989. The underground economies: Tax evasion and information distortion (Cambridge University Press: Cambridge, UK).

Feige, E.L., 1996. Overseas holdings of U.S. currency and the underground economy. In: Pozo, S. (ed), Exploring the Underground Economy (W.E. Upjohn Institute for Employment Research: Kalamazoo USA), 5-62.

Feige, E.L.; Urban, I., 2008. Measuring underground (unobserved, non-observed, unrecorded) economies in transition countries: Can we trust GDP?. Journal of Comparative Economics 36, 287-306.

Feinstein, J.S., 1990. Detection controlled estimation. Journal of Law and Economics 33, 233-276.

Feinstein, J.S., 1991. An econometric analysis of income tax evasion and its detection. Rand Journal of Economics 22, 14-35.

Feld, L.P.; Frey, B.S., 2002. Trust breeds trust: How taxpayers are treated. Economics of Governance 3, 87-99.

Feld, L.P.; Schneider, F., 2010. Survey on the shadow economy and undeclared earnings in OECD countries. German Economic Review 11(2), 109-149.

Frey, B.S.; Weck-Hannemann, H., 1984. The hidden economy as an "unobserved" variable. European Economic Review 26(1), 33-53.

Gerxhani, K., 2007. "Did you pay your taxes?” How (not) to conduct tax evasion surveys in transition countries. Social Indicators Research 80, 555-581.

Giles, D., 1999. Modelling the hidden economy in the tax-gap in New Zealand. Empirical Economics 24(4), 621-640.

Gutmann, P., 1977. The subterranean economy. Financial Analysts Journal 34, 26-28.

Hanousek, J.; Palda, F., 2004. Quality of government services and the civic duty to pay taxes in the Czech and Slovak Republics, and other transition countries. Kyklos 57(2), 237-252.

Helberger, C.; H. Knepel, 1988. How big is the shadow economy? A re-analysis of the unobserved-variable approach of B.S. Frey and H. Weck-Hannemann. European Economic Review 32(4), 965-976.

IRS. 1983. Income tax compliance research: Estimates for 1973-81, US Internal Revenue Service Report. 
Isachsen, A.J.; Strom, S., 1985. The size and growth of the hidden economy in Norway. Review of Income and Wealth 31(1), 21-38.

Johnson, S.; Kaufmann, D.; Schleifer, A., 1997. The unofficial economy in transition. Brookings Papers on Economic Activity 2, 159-239.

Johnson, S.; Kaufmann, D.; Zoido-Lobaton, P., 1998. Regulatory discretion and the unofficial economy. American Economic Review 88(2), 387-392.

Kaufmann, D.; Kaliberda, A., 1996. Integrating the unofficial economy into the dynamics of post-socialist economies: A framework of analysis and evidence. In: Kaminski and Barlomiej (eds), Economic transition in Russia and the new states of Eurasia. International Politics of Eurasia Series Vol. 8 (Sharpe: Armonk and London), 81120.

Kazemier, B.; van Eck, R., 1992. Survey investigations of the hidden economy. Journal of Economic Psychology 13, 569-587.

Kim, B.-Y., 2003. Informal economy activities of Soviet households: Size and dynamics. Journal of Comparative Economics 31, 532-551.

Kovács, G.; Spens, K.M., 2006. Transport infrastructure in the Baltic States post-EU succession. Journal of Transport Geography 14, 426-436.

Lackó, M., 2000. Hidden economy - An unknown quantity? Comparative analysis of hidden economies in transition economies, 1989-95. Economics of Transition 8(1), 117-149.

Laurila, J., 2003. Transit transport between the European Union and Russia in light of Russian geopolitics and economics. Emerging Markets Finance and Trade 39(5), 27-57.

MacAfee, K., 1980. A glimpse of the hidden economy in the National Accounts. Economic Trends 1980(8), 81-87.

Mogensen, G.V.; Kvist, H.K.; Körmendi, E.; Pedersen, S., 1995. The shadow economy in Denmark 1994: Measurement and results. Study No. 3 (The Rockwool Foundation Research Unit: Copenhagen).

OECD, 2002. Measuring the Non-Observed Economy: A Handbook. (OECD: Paris, France).

Petersen, H.G., 1982. Size of the public sector, economic growth and the informal economy: Development trends in the Federal Republic of Germany. Review of Income and Wealth 28, 191-215. 
Rosser, J.B.; Rosser, M.V.; Ahmed, E., 2000. Income inequality and the informal economy in transition economies. Journal of Comparative Economics 28, 156-171.

Sandmo, A., 2005. The theory of tax evasion: A retrospective view. National Tax Journal $58,643-663$.

Sauka, A., 2008. Productive, unproductive and destructive entrepreneurship: A theoretical and empirical exploration (Frankfurt am Main: Peter Lang GmbH).

Schneider, F., 2013. Size and development of the shadow economy of 31 European and 5 other OECD countries from 2003 to 2013: A further decline. Unpublished manuscript.

Schneider, F.; Buehn, A.; Montenegro, C., 2010. New estimates for the shadow economies all over the world. International Economic Journal 24(4), 443-461.

Schneider, F.; Enste, D., 2000. Shadow economies: Size, causes, and consequences. Journal of Economic Literature 38(1), 77-114.

Slemrod, J., 2007. Cheating ourselves: The economics of tax evasion. Journal of Economic Perspectives 21(1), 25-48.

Slemrod, J.; Webber, C., 2012. Evidence of the invisible: Toward a credibility revolution in the empirical analysis of tax evasion in the informal economy. International Tax and Public Finance.

Tanzi, V., 1980. Underground economy built on illicit pursuits is growing concern of economic policymakers. Survey 4-2-1980 International Monetary Fund, 34-37.

Tanzi, V., 1983. The underground economy in the United States: Annual estimates, 19301980. IMF Staff Papers 30, 283-305.

Thomas, J.J., 1992. Informal Economic Activity, Handbooks in Economics, (Harvester Wheatsheaf: London, UK).

Vadi, M.; Jaakson, K., 2011. The dual value of honesty among Russians in selected former Soviet countries. Cross Cultural Management: An International Journal 18(1), 55-70.

Warren, E., 2003. Constructive and destructive deviance in organizations. Academy of Management Review 28(4), 622-631.

Williams, C.C., 2008. Illegitimate wage practices in Eastern Europe: The case of “envelope wages". Journal for East European Management Studies 13(3), 253270.

Williams, C.C., 2013. Out of the shadows: A classification of economies by the size and character of their informal sector. Work, Employment and Society (forthcoming). 
Williams, C.C.; Windebank, J., 1995. Black market work in the European community: Peripheral work for peripheral localities?. International Journal of Urban and Regional Research 19, 23-39.

Yitzhaki, S., 1974. A note on income tax evasion: A theoretical analysis. Journal of Public Economics 3(2), 201-202.

Zienkowski, L., 1996. Polish experience in estimating hidden economy, Unpublished manuscript. 
Table 1. Size of the shadow economy in the Baltic countries 2009-2012

This table reports point estimates and $95 \%$ confidence intervals for the size of the shadow economies as a proportion of GDP. The last column reports the change in the relative size of the shadow economy from 2011 to 2012.

\begin{tabular}{lccccc}
\hline & 2009 & 2010 & 2011 & 2012 & $2012-2011$ \\
\hline Estonia & $20.2 \%$ & $19.4 \%$ & $18.9 \%$ & $19.2 \%$ & $+0.3 \%$ \\
& $(18.7 \%, 21.7 \%)$ & $(18.0 \%, 20.8 \%)$ & $(16.8 \%, 20.9 \%)$ & $(16.6 \%, 21.9 \%)$ & $(-2.0 \%, 2.8 \%)$ \\
Latvia & $36.6 \%$ & $38.1 \%$ & $30.2 \%$ & $21.1 \%$ & $-9.1 \%$ \\
& $(34.3 \%, 38.9 \%)$ & $(35.9 \%, 40.3 \%)$ & $(27.6 \%, 32.7 \%)$ & $(18.5 \%, 23.6 \%)$ & $(-11.7 \%,-6.5 \%)$ \\
Lithuania & $17.7 \%$ & $18.8 \%$ & $17.1 \%$ & $18.2 \%$ & $+1.1 \%$ \\
& $(15.8 \%, 19.7 \%)$ & $(16.9 \%, 20.6 \%)$ & $(15.2 \%, 19.0 \%)$ & $(16.4 \%, 20.1 \%)$ & $(-0.7 \%, 3.0 \%)$ \\
\hline
\end{tabular}


Table 2. Determinants of firms' involvement in shadow activity.

This table reports coefficients from regressions of firms' unreported proportion of production in 2012 (dependent variable) on various determinants of shadow activity, using the pooled sample of Estonian, Latvian, and Lithuanian firms. $D_{-} E E$, and $D_{-} L T$ are dummy variables for Estonian and Lithuanian firms, respectively (Latvian firms are the omitted category). Tolerance_TaxEvasion is the firm's response to Q5, with higher scores indicating more tolerance. Satisfaction is the first principal component of the firm's responses to Q1-Q4, with higher scores indicating higher satisfaction with the country's tax system and government. DetectionProbability and PenaltyForDetection measure the firm's perception of the probability of being caught for shadow activity and the severity of penalties conditional on being caught (calculated as the first principal component of responses to Q16(i)Q16(iv), and the response to Q17, respectively). $\ln$ (FirmAge) and $\ln$ (Employees) are the natural logarithms of the firm's age in years and its number of employees. AverageWage is the average monthly salary in EUR paid by the firm. ChangeInProfit is the firm's percentage change in net sales profit from 2011 to 2012. D_Wholesale to D_OtherSector are sector dummy variables with manufacturing as the omitted category. ***,** and * indicate statistical significance at the $1 \%, 5 \%$ and $10 \%$ levels. T-statistics are reported in parentheses.

\begin{tabular}{|c|c|c|c|}
\hline & Model 1 & Model 2 & Model 3 \\
\hline Intercept & $\begin{array}{c}30.502 * * * \\
(4.24)\end{array}$ & $\begin{array}{c}24.578 * * * \\
(2.85)\end{array}$ & $\begin{array}{c}22.368 * * * \\
(5.60)\end{array}$ \\
\hline D_EE & $\begin{array}{l}-2.103 \\
(-0.68)\end{array}$ & & \\
\hline D_LT & $\begin{array}{l}-3.026 \\
(-0.99)\end{array}$ & & \\
\hline Tolerance_TaxEvasion & $\begin{array}{c}1.781 * * \\
(2.28)\end{array}$ & $\begin{array}{c}1.932 * * \\
(2.38)\end{array}$ & $\begin{array}{c}2.423 * * * \\
(3.64)\end{array}$ \\
\hline Satisfaction & $\begin{array}{c}-1.738^{*} \\
(-1.78)\end{array}$ & $\begin{array}{c}-2.022^{*} \\
(-1.91)\end{array}$ & $\begin{array}{c}-1.962 * * \\
(-2.28)\end{array}$ \\
\hline DetectionProbability & $\begin{array}{c}-2.847 * * * \\
(-2.79)\end{array}$ & $\begin{array}{c}-3.042 * * * \\
(-2.81)\end{array}$ & $\begin{array}{c}-2.709 * * * \\
(-2.96)\end{array}$ \\
\hline PenaltyForDetection & $\begin{array}{l}-0.144 \\
(-0.15)\end{array}$ & $\begin{array}{l}-0.049 \\
(-0.05)\end{array}$ & \\
\hline $\ln ($ FirmAge $)$ & $\begin{array}{l}-1.976 \\
(-0.98)\end{array}$ & $\begin{array}{l}-0.715 \\
(-0.33)\end{array}$ & \\
\hline $\ln$ (Employees) & $\begin{array}{c}-1.458 * * \\
(-2.18)\end{array}$ & $\begin{array}{c}-1.335^{*} \\
(-1.86)\end{array}$ & $\begin{array}{c}-1.265^{* *} \\
(-2.21)\end{array}$ \\
\hline AverageWage & $\begin{array}{c}0.000 \\
(-0.27)\end{array}$ & $\begin{array}{l}-0.001 \\
(-0.61)\end{array}$ & \\
\hline ChangeInProfit & $\begin{array}{l}0.014 \\
(1.05)\end{array}$ & $\begin{array}{l}0.012 \\
(0.85)\end{array}$ & \\
\hline D_Wholesale & $\begin{array}{l}-1.849 \\
(-0.68)\end{array}$ & $\begin{array}{l}-1.994 \\
(-0.71)\end{array}$ & $\begin{array}{l}-1.608 \\
(-0.67)\end{array}$ \\
\hline D_Retail & $\begin{array}{l}-0.256 \\
(-0.09)\end{array}$ & $\begin{array}{l}0.012 \\
(0.00)\end{array}$ & $\begin{array}{l}-1.066 \\
(-0.45)\end{array}$ \\
\hline D_Services & $\begin{array}{l}-1.267 \\
(-0.50)\end{array}$ & $\begin{array}{l}-1.469 \\
(-0.54)\end{array}$ & $\begin{array}{l}-2.321 \\
(-1.09)\end{array}$ \\
\hline D_Construction & $\begin{array}{l}4.482 \\
(1.39)\end{array}$ & $\begin{array}{l}4.938 \\
(1.41)\end{array}$ & $\begin{array}{l}3.424 \\
(1.25)\end{array}$ \\
\hline D_OtherSector & $\begin{array}{l}1.760 \\
(0.31)\end{array}$ & $\begin{array}{l}3.447 \\
(0.57)\end{array}$ & $\begin{array}{l}-5.035 \\
(-1.23)\end{array}$ \\
\hline $\begin{array}{l}\text { Country*Region } \\
\text { dummy variables }\end{array}$ & No & Yes & Yes \\
\hline Adjusted R-squared & $8.9 \%$ & $12.2 \%$ & $12.6 \%$ \\
\hline
\end{tabular}


Estonia:

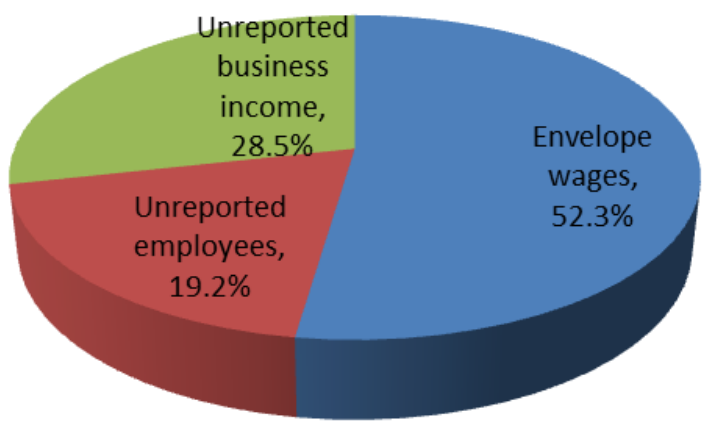

Latvia

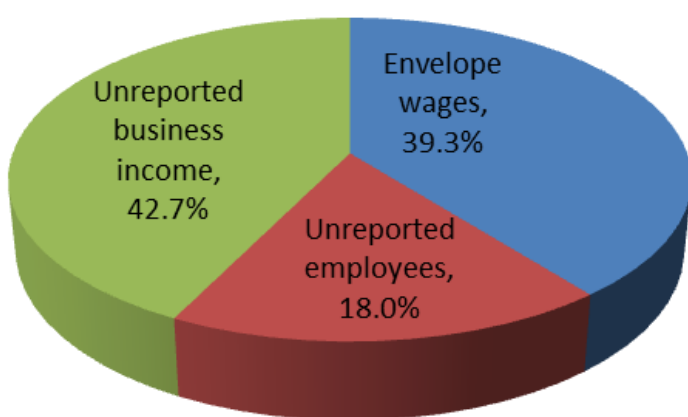

Lithuania

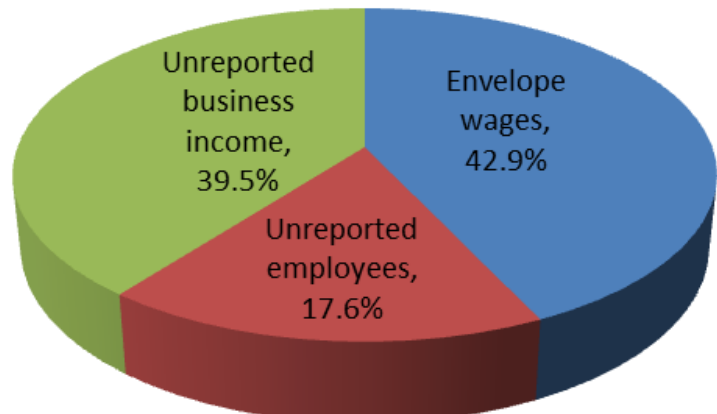

Figure 1. Components of the shadow economies in each of the Baltic countries, 2012. 
Performance of companies in your industry is very much influenced by their choice to pay or evade taxes: by evading taxes firms in your industry considerably increase their profits.

Performan ce of your company very much depends on the eco nomic situation in the country: your company performs considerably better during econo mic growth, but during economic recession performance gets considerably worse.

To ensure successful performance of a company (including survival) it is much more important to have appropriate product and business strategies than to evade taxes.

Tax evasion is primarily entrepreneurs' response to what they believe are incorrect actions by the state with regard to promoting entrepreneurship.

Entrepreneurs in Latvia trust the Government, and believe that their tax money is spent appropriately.

Whenever possible, entrepreneurs will try to decrease their business costs, which also includes evading taxes, regardless of the nature of the Government's entrepreneurship policy in Latvia [state support, tax legislation, etc.)

Whenever possible, entrep ren eurs will try to decrease their business costs, which also includes evading taxes, regard less of how their company performs.

Entrepreneurs in your in dustry evade taxes because this is the only way to survive.

Firms in your ind ustry tend to evade taxes more if they are having relatively bad times (for instance, decrease in profits or turnover in comparison to previous years]

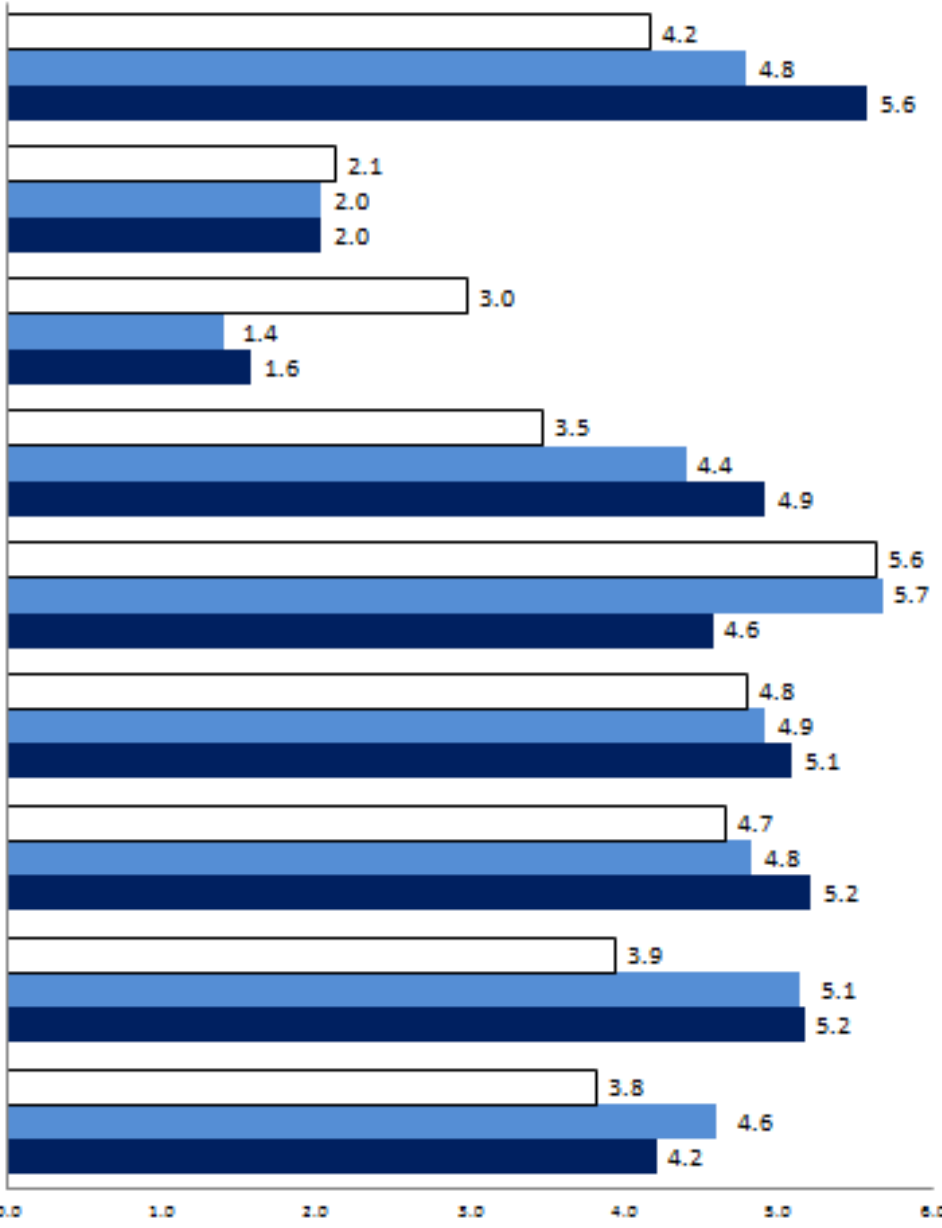

$\square \mathrm{LV} \square \mathrm{LT} \square \mathrm{EE}$

Figure 2: Company managers' attitudes regarding tax evasion. 